\title{
Twenty years wandering (but not in the desert): Brazil's 1967-1989 absence from UN peacekeeping
}

\author{
Eduardo Uziel \\ João Augusto Costa Vargas ${ }^{1}$
}

“In 1956, Brazilian troops were sent to the first United Nations Emergency Force in Suez (UNEF). Since then, Brazil has participated in 33 United Nations peacekeeping operations and contributed with over 27,000 troops." (Viotti, 2011) This statement, by former Brazilian Permanent Representative to the United Nations Maria Luiza R. Viotti, is fairly typical example of how Brazil sees itself in the UN context. For the past two decades, Brazil's role as a traditional contributor of troops to peacekeeping operations has been a recurrent element in the country's diplomatic discourse. It has often been cited as a factor underpinning the country's ambitions to become a permanent member of the Security Council and as an asset in its most recent campaign to occupy a nonpermanent seat on that body (MRE, 2009; Amorim, 1995; Seixas Corrêa, 2012; Cardoso, 1998).

Yet from 1967 to 1989 Brazil did not take part in any peacekeeping operations. Although there were relatively few operations in that period ${ }^{2}$, Brazil's complete lack of contribution is still somewhat odd, given that it contributed to peacekeeping missions between 1956 and 1967. Even more puzzling is that Brazil's absence from peacekeeping

\footnotetext{
${ }^{1}$ The opinions of the authors are solely their own and do not necessarily reflect those of the Ministry of External Relations.

${ }^{2}$ In contrast with the dozens of peacekeeping operations created since 1989, only five were established from 1967 to 1988; three others had been created before 1967 and remained in existence after that year - to this day, in fact. See http://www.un.org/en/peacekeeping/documents/operationslist.pdf, accessed on 1/4/2015.
} 
coincided with a particularly active period in its UN diplomacy, when it took a vocal role on a number of international security issues. Why, then, the curious lack of participation in peacekeeping missions?

At first glance, one might be tempted to blame Brazil's withdrawal on the 1964 coup d'état that established Brazil's military dictatorship, or on the deepening of political repression after 1968. Upon further study, however, this explanation is unconvincing. There is no empirical evidence to suggest that authoritarian regimes do not or cannot contribute to peacekeeping missions ${ }^{3}$, and in Brazil's case, even after the coup, the contribution to UNEF I continued until that mission's dissolution in 1967. Even the cautious process of political liberalization begun in the late 1970s did not lead to Brazil's return to peacekeeping: on the contrary, in 1977, Brazil distanced itself even further from the debates on the issue. The explanation for the Brazilian absence should thus be sought in a more complex understanding of the country's perception of international reality and of its role in it.

This article examines the worldview that discouraged Brazil from participating in UN peacekeeping operations from 1967 to 1989. It is divided in five sections, followed by a brief conclusion: the first analyses Brazil's pre-1967 contributions to peacekeeping; the second contextualizes the roots of Brazilian multilateral activism from the late 1960s to the early 1980s; the third explores the limits of that activism and why peacekeeping fell outside of those limits; the fourth considers other factors that may have influenced policymakers' attitudes towards peacekeeping; and the fifth briefly examines how Brazil reentered the world of UN peacekeeping in the late 1980s.

\footnotetext{
${ }^{3}$ The studies by Andersson do not exclude participation by authoritarian regimes, they underline the willingness of democracies to contribute (Andersson, 2000; Andersson, 2002).
} 


\section{From San Francisco to Rafah - Brazil's initial experience with peacekeeping:}

Brazil was an active belligerent in the Second World War and a founding member of the United Nations. Like most Latin American countries, it had a cautious attitude towards the new system of collective security, fearing that it would spell the end of Washington's commitment to the Americas. Nevertheless, Brazil participated energetically in the young Organization, including by serving a number of elected terms on the Security Council (1946-1947, 1951-1952 and 1954-1955). While in the General Assembly and the Economic and Social Council, Brazil sought to obtain concrete gains in areas such as technical and development cooperation, in the Security Council, Brazil's approach was closer to "prestige multilateralism", without immediate material reward (Campbell, 1973: 111-129; Uziel, 2010: 131-161; Bueno, 1994: 61-72). There, Brazilian diplomats largely supported the positions of the United States, particularly regarding issues where there was a clear cleavage between Washington and Moscow, but managed to preserve some degree of independence.

From 1946 to 1967, Brazil took part in eight different peacekeeping operations: $\mathrm{UNSCOB}^{4}$, in Greece; DOMREP5, in the Dominican Republic; UNFICYP, in Cyprus; UNYOM, in Yemen; ONUC, in the Congo; UNSF, in Irian Java; UNIPOM, in India and Pakistan; and UNEF I, in Suez. Of those, the contribution to UNEF I was by far the most significant, both in terms of troops committed (a full battalion of 600 per year) and of the internal political debate that followed on the pros and cons of sending Brazilian soldiers

\footnotetext{
${ }^{4}$ Although UNSCOB is not officially considered a peacekeeping mission, its characteristics are very similar to those of the late 1940s observer missions.

${ }^{5}$ The United Nations mission DOMREP should not be confused with the so-called "inter-American force" that preceded it and effectively occupied the country. Brazil's participation in that force was significant and controversial; its contribution to DOMREP was minor and passed largely unnoticed.
} 
to United Nations peacekeeping missions (Fontoura, 2009). Grasping why Brazil chose to begin contributing to peacekeeping in 1956 is key to understanding its decision to stop after 1967.

The decision to contribute to UNEF I resulted from a confluence of three factors. In the years since 1947, Brazil had been involved in the multilateral debates and actions on the Middle East. These included the role of Oswaldo Aranha, who presided the General Assembly session that approved the partition of Palestine, and the involvement in negotiation of Security Council decisions that attempted to mitigate the conflict between Israel and its Arab neighbors. Those recent events fostered in Brazilian diplomacy a sense of responsibility for the developments in the Middle East, which certainly helped lead the country to send its troops to a region that, in the 1950s, was still considered very far away (Santos, 2000: 34-38).

A second factor that encouraged Brazil to take part in UNEF I was its constant advocacy for a greater role for middle and small powers in the United Nations. Brazil had been pushing this issue since the San Francisco Conference and continued to do so in the debates on the Suez crisis and the establishment of the peacekeeping mission. When requesting the Brazilian Congress to authorize the deployment of troops to UNEF I, the Ministry of External Relations emphasized that the mission's establishment was directly linked to the Uniting for Peace resolution (resolution 377 A (V)), which Brazil had actively helped to negotiate, seeking not only to support the position of the United States, but principally to strengthen the role of the General Assembly (Brasil, 1956a: $11187-11188)^{6}$.

\footnotetext{
${ }^{6}$ Brazil, alongside Canada, Ceylon, Colombia, India, Norway and Pakistan, was chosen to be a member of the UNEF advisory committee, established in accordance with General Assembly resolution 1001 (ES-I), of 11/7/1956 (http://www.un.org/en/peacekeeping/missions/past/uneflbackgr2.html, accessed on 1/8/2015).
} 
The third factor referred to broader changes in Brazilian foreign policy, stemming from the evolution of policymakers' worldview. President Juscelino Kubitschek (19561961) had a vision of rapid progress for Brazil which, in the external arena, translated into a more activist approach to affirming the country's relevance and interests. This activism was coupled with an effort to work more closely with the United States both in the Americas and around the world - a purpose for which UNEF I was particularly well suited (Weis, 1993: 113-140). The same request to Congress mentioned above underlined that the dynamism of international politics, as demonstrated by the emergence of new nations and conflicts, required Brazil to take a more prominent role in international affairs and take concrete actions to put into practice its traditional defense of the principles of international liberty and justice. In the words of the Minister of External Relations, the Brazilian contingent "(...) would demonstrate that we can and we will, when time comes, come to the forefront of the international system, a natural position to which we cannot renounce" (Brasil, 1956a: 11188; Lannes, 2009: 64-83; Bueno \& Cervo, 2001: 287-307).

Congress approved the request to send troops to Suez, but not before opposition politicians raised a series of objections, which would resurface in the future. The first was the concern that instead of keeping the peace, Brazilian troops might end up involved in a larger conflict, into which Brazil might be drawn against its will. Secondly, there was a fear that peacekeeping might be manipulated to serve the great powers' interests, to the detriment of Brazil's own interests and principles. Critics pointed to the lack of international action with regards to the Hungarian crisis, suggesting that neglecting Hungary while rushing to Suez would be an endorsement of unjust double standards. Finally, it was charged that Brazil, as a developing country, could not afford to squander its resources in foreign adventures and should direct its attentions inwardly 
(Brasil, 1956a: 11187-11195; Brasil, 1956b: 11237-11248 and 11283-11284; Brasil, 1956c: 11467-11472; Brasil, 1956d: 11514-11526)

The Brazilian troops remained in the Middle East from early 1957 to June 1967, when the Six Days War resulted in UNEF I being disbanded. For two years, Brazilian generals commanded the Force. The mission's withdrawal, however, was a chaotic affair, that left bad memories among the soldiers and officers involved. There were difficulties in evacuating the battalion, which was caught in the crossfire. It only managed to leave the Middle East and return to Brazil after the conclusion of the war, having suffered casualties (Fontoura, 2005: 214-216; Santos, 2002; United Nations, 2014; Arraes Filho, 2008). Following the dissolution of UNEF I, Brazil would not return to UN peacekeeping until 1989.

\section{The Roots of Brazil's Multilateral Activism:}

Taken by itself, Brazil's absence from peacekeeping between 1967 and 1989 is not particularly noteworthy. Many other countries also refrained from participating in these missions. What is striking about the Brazilian case is that the withdrawal from peacekeeping occurred simultaneously with a notable uptick in Brasília's multilateral activism, including in the sphere of international security. This activism reflected changing views of the kinds of international support required to spur the country's development. From the mid-1930s, Brazil had focused on extracting bilateral aid and technical assistance from the United States. This approach proved particularly effective before and during World War II, when Brazil's strategic value rendered the American government particularly generous (Moura, 1980). 
After the war, however, Washington's increased focus on the Cold War being waged in Europe and Asia resulted in dwindling support for Brazilian development. Beginning with the Kubitschek government (1956-1961), policymakers sought to place their requests for aid in a more contemporary political context, through efforts such as the "Operation Pan-America", which attempted to portray American financing for Latin American development as a form of combating communism in the Western Hemisphere (Mello e Silva, 1992).

In the Quadros (1961) and Goulart (1961-1964) administrations, the so-called "Independent Foreign Policy" took this link between economic development and international politics even further. Brazilian diplomacy took heed of the economic work of Raul Prebisch and of the increasingly robust denunciation of the injustice of the international system by the newly-decolonized countries of Africa and Asia. In New York and Geneva, Brazil's representatives took on a leading role in calling for stronger multilateral institutions, that could provide a more robust and supportive framework for the development of Third World countries (Brito Cruz, 1989; Ligiéro, 2011).

In 1964, the military coup d'état led to what has been called an "out of step" moment in Brazilian foreign policy (Bueno \& Cervo, 2001: 368-373). Under Castello Branco (1964-1967), the new regime sought to burnish its pro-Washington credentials by putting aside concerns with international inequality and adopting a rhetoric focused on East-West issues and the dangers of "communist subversion".

In 1967, however, with the inauguration of General Artur da Costa e Silva, Brazil returned to a more nationalistic discourse. Costa e Silva, like his successors in the military regime, represented a section of the Army whose instinctive and profound anticommunism was matched by an almost obsessive concern with Brazil's economic development. They did not shirk from criticizing what they considered unfair efforts by 
the developed countries to hamper the progress of developing countries - while, practically in the same breath, reaffirming their allegiance to the cause of the West in the Cold War (Vizentini, 2004: 77-81; Altemani de Oliveira, 2005: 124-131).

The technocratic nature of Brazil's military regime meant that the Ministry of External Relations had considerable leverage over foreign policy. Therefore, to understand the multilateral activism demonstrated by Brazil from 1967 onwards, it is helpful to analyze the worldview that predominated among key Brazilian policymakers (Hurrell, 2013; Lima, 1992; Pinheiro, 2000). This worldview was comprised of four main elements. The first was a concern with Brazil's development: economic progress was seen as the ultimate objective of foreign policy. A second element was a belief in Brazil's "destiny" - a conviction that the country's size, resources and population allowed it an important role not only in regional, but also global politics.

The third element was the conviction that economic ends would have to be achieved by political means, forged at the United Nations Conference on Trade and Development (UNCTAD, 1964) and epitomized in the G-77.7 Accepting the postulate that underdevelopment resulted at least in part from international structures, Brazilian diplomats believed that political pressure was required on an international level to change those structures and open the door to development.

Finally, the worldview of the Brazilian Ministry of External Relations was strongly influenced by what Ambassador João Augusto de Araujo Castro called "the freezing of world power". ${ }^{8}$ This referred to the process by which the great powers

\footnotetext{
${ }^{7}$ The Group of 77, or G-77, is a coalition of developing countries established by the "Joint Declaration of the Seventy-Seven Developing Countries", issued at the end of the first session of UNCTAD. Concerning itself essentially with development, trade, and economic issues, the Group became an active vehicle for Brazil and other developing countries at the United Nations.

${ }^{8}$ João Augusto Araujo Castro (1919-1975) was perhaps the most influential Brazilian diplomat of the Cold War period. Having occupied a number of important positions such as Minister of External Relations (1963-1964), 
sought, through tacit or explicit understandings, to preserve their privileged place in the international system, for instance, by enshrining the veto power in the UN Charter or the monopoly on nuclear weapons in the Nuclear Non-Proliferation Treaty (NPT). Although later decried by some critics as "an invitation to a conspiratorial interpretation of history", the "freezing of world power" proved itself a potent conceptual lens for Brazilian diplomacy, which led policymakers to focus on how and where the great powers sought to establish the rules of the international system (Campos, 2004: 865).

Taken together, these factors led Brazil to adopt an assertive, activist role in multilateral fora - including in debates and discussions about international security. Brazil was an active participant in the Eighteen Nation Committee on Disarmament (ENCD), where, in a context of mutual suspicion and disagreement between the superpowers, it sought to help achieve an agreement along the lines of what ended up becoming the Partial Test-Ban Treaty. Brazil used its 1967-1968 term on the Security Council as a platform to question the manner in which the superpowers sought to deal with international conflicts - particularly in the Middle East and in Czechoslovakia. In the UN General Assembly, Brazilian diplomats not only helped to lead the charge against what they denounced as the "undisguisable institutionalization of inequality between States" enshrined the Non-Proliferation Treaty (Vizentini, 2004: 114-116; Amado, 1982: 100), but also expended considerable time and effort in trying to promote a broader re-think of the UN's role in international security (Cançado Trindade, 1981: 181-182; Amado, 1982: 109-117).

Permanent Representative to the United Nations in New York (1968-1971), and Ambassador to the United States (1971-1975), he is most well known for his intellectual influence over his peers and his contribution to Brazil's view of the international system during the 1960s and 1970s (Vargas 2013). 


\section{The Limits of Brazil's Multilateral Activism - the case of peacekeeping:}

For Brazil, therefore, security issues were a means to an end, rather than the result of direct concerns with military threats or resolution of particular conflicts. In some instances, Brazil's engagement reflected a concern on the underlying implications for development. This was at least partly the case with the NPT, which policymakers feared would hinder the country's access to peaceful nuclear technology that might help accelerate economic progress. ${ }^{9}$

In other cases, Brazil's concern with security issues was spurred by the fear that the rhetoric of promoting peace was being used by the great powers to erode other states' autonomy and sovereignty in ways that could harm Brazil in the future. A clear example of this was Brazil's strident condemnation of the USSR's enunciation of the Brezhnev Doctrine and the United States' tacit acceptance of it, after the invasion of Czechoslovakia. ${ }^{10}$

In this context, the peacekeeping gap in Brazil's multilateral activism becomes easier to understand. Peacekeeping operations did not appear to directly affect Brazil's developmental prospects or even its economic interests more broadly - Brazil had no major commercial interests in the countries where the operations were deployed, for

\footnotetext{
${ }^{9}$ Brazilian officials were frequently vague and imprecise regarding the precise contribution that nuclear power would make to national development. For instance, President Costa e Silva, during a meeting of Brazil's National Security Council, averred that "peaceful nuclear explosions" might have relevant trade implications. These flights of fancy were not restricted to Brazil: a 1967 cable from the Brazilian Embassy in Peru mentioned that President Belaúnde had publicly referred to the possibility of using nuclear explosions to undertake major public works, such as building dams (Spektor, forthcoming; Brasemb Lima, 1967).

${ }^{10}$ While forcefully condemning the Soviet invasion of Czechoslovakia, Brazil also expressed concern with the fact that the Western powers "did not sufficiently denounce the very dangerous doctrine" which underpinned the invasion, i.e., the idea that the superpowers could legitimately intervene in countries within their respective "spheres of influence". Brazil publicly rejected that notion that "a new Tordesilhas" might divide the world between the US and the USSR (Amado, 1982: 133-134 and 148).
} 
instance. Moreover, to Brazilian eyes, the theory and practice of United Nations peacekeeping operations did not seem to threaten the sovereign equality of states or their capacity for autonomous action.

However, one aspect of peacekeeping operations did concern Brazilian diplomats. Peacekeeping was not foreseen in the UN Charter and the legal basis for these operations was therefore ambiguous. This kind of ambiguity suggested wide latitude for the Security Council - in particular, its permanent members - to act in a wholly unconstrained fashion, with unpredictable consequences for the missions, the UN Charter, and the Organization as a whole.

Brazil might have been inclined to consider contributing to peacekeeping operations if it felt that doing so might enhance its ability to participate in defining their legal basis. Neither the experience with UNEF I, nor the day-to-day work of the United Nations endorsed this view. On the contrary, there was already a perception that the permanent members of the Security Council were engaged in a conscious effort to strengthen their control over peacekeeping missions, to the detriment of the elected members of the Council, the General Assembly, and, to a certain extent, the SecretaryGeneral himself (Delbrasonu, 1973a; Delbrasonu, 1973e; SERE, 1973b).

In this context, it is not surprising that when the Second United Nations Emergency Force (UNEF II) was created in 1973, Brazil did not demonstrate interest in participating. The Brazilian Mission to the UN cabled Brasília detailed reports on the discussions regarding the composition of the peacekeeping force, but at no point suggested that Brazil might participate. References to this possibility are similarly absent in the cables sent back from the Ministry of External Relations (Delbrasonu, 1973c; Delbrasonu, 1973d). 
If Brazil did not consider contributing troops to peacekeeping, how did it view the possibility of more sustained engagement in the discussions on peacekeeping happening in New York? This was, after all, a fervent time for such discussions (Urquhart, 1987: 240). The financing of peacekeeping operations was a controversial issue and the International Court of Justice's 1962 advisory opinion on the matter did little to quell the related debates in New York (Delbrasonu, 1963e; United Nations, 1962: 151-181; Review, 1999; Claude, 1963). The creation of UNEF II put back on the table a number of concrete issues regarding the political and logistic management of peacekeeping, including which countries would contribute troops, a subject hammered out by the states and not left to the Secretariat as today.

At first, Brazil engaged vigorously in these deliberations, impelled by apprehensions regarding the gradual concentration of control and oversight of peacekeeping in the hands of the permanent members of the Security Council (Uziel, 2010). This tendency, if left unchecked, could compromise the usefulness of peacekeeping as a tool for the UN, reducing it to an instrument to advance great power interests (along the same lines of the arguments made in Congress against Brazil's participation in UNEF I in 1956). Moreover, Brazil increasingly felt that the Council as a whole was slowly being appropriated as a venue to consolidate bilateral agreements reached between Moscow and Washington and losing its character as an independent political body (Araujo Castro, 1972; SERE, 1977), which made the issue even more urgent. These concerns were very explicit in instructions that the Ministry of External Relations sent the Brazilian Mission to the UN on the question of peacekeeping: "the freezing of world power in the hands of a few States, be they the permanent members of the Security Council or the two superpowers, is against the interests of Brazil" (SERE, 1973b). 
In light of this, Brazil sought to promote a series of initiatives, including a possible Charter amendment to deal with peacekeeping (SERE, 1973a; SERE, 1973b) and the presentation, in the General Assembly, of a series of "principles" to guide the functioning of these operations (Delbrasonu, 1973b). In the General Assembly's Special Committee on Peacekeeping Operations (the $\mathrm{C}-33^{11}$ ), Brazil, alongside other countries such as Argentina, Egypt, India, Nigeria, and Pakistan, tried to bridge the differences between Member States and define clearly the roles of the Council, the General Assembly, and the Secretary General in the establishment and management of peacekeeping operations.

Brazil hoped that by reaching a modicum of agreement on such issues, the Assembly would remain an important forum for the discussion of peacekeeping and keep the Security Council from monopolizing control of these operations. It hoped thereby to consolidate in the United Nations a model for peacekeeping similar to that which had governed UNEF I, in which the General Assembly and the Secretary General retained sizable influence of the operation - and Brazil was a member of the committee in charge of supervising the force.

These efforts yielded few results, and by the mid-1970s, Brazil's patience with discussions on peacekeeping was wearing thin. In smaller forums such as the C-33 (and the Security Council ${ }^{12}$ ), Brazilian negotiators could count on relatively few allies to

\footnotetext{
${ }^{11}$ From its inception in 1966 to 1988, the Special Committee on Peacekeeping Operations was known as the C-33, in view of its membership; when China joined in 1988, it started being called the C-34, a term still used at the UN jargon, although the Committee has over 100 members today. (Uziel \& Vargas, 2011: 166-181).

12 Brazil's absence from the Security Council between 1968 and 1988 is a similar but distinct issue that merits greater attention than it has received. Although some of the reasons for this absence were analogous to those for Brazil's withdrawal from peacekeeping, the two cases have a number of distinct features, perhaps chief among them being the importance of the issue of Portuguese colonies in Africa to Brazil's calculations on whether to return to the Security Council after its 1967-1968 term. Distancing Brazil from the Council appears to have been less consensual position within the Ministry of External Relations than deciding not to participate in peacekeeping operations (Vargas, 2013: 201-203).
} 
support their positions and constantly ran the risk of being isolated (Delbrasonu, 1973f). There was no imposing voting bloc of developing countries such as those that could be marshaled in the full General Assembly or in the Economic and Social Council. Therefore, participating in the discussions of the C-33 was a frustrating exercise, with little chance of securing desirable outcomes while expending valuable human resources and political capital.

The result was that, in 1977, Brazil left the C-33, the final step in the process of distancing itself from peacekeeping operations that began with the drawdown of UNEF I. The reasons for the withdrawal from the Special Committee were laid out in a cable sent from the Ministry of External Relations to the Brazilian Mission to the UN in May of 1977(SERE, 1977). The cable observed that since the C-33's first session in 1966, it had failed to make significant progress towards the creation of guidance for peacekeeping, notwithstanding considerable efforts in this regard by Brazil and other countries. This failure was laid at the feet of the US, UK, France and the Soviet Union (China was not a member of the C-33 at that point), who, "despite their disagreements, in reality agree on preserving for themselves the monopoly on decision-making regarding peacekeeping operations" and exercised a "virtual veto power" that hampered the Committee's operation. In light of these obstacles, the efforts by Brazil and other developing countries to bring the Committee to substantive agreement achieved only "modest results".

The cable went on to state that this state of matters was likely to persist and that it was therefore necessary to "redefine Brazil's position". It cited Brazil's "reduced interest" in shouldering "the burden of a leadership role" in efforts to exert pressure on the superpowers in the C-33 and noted that discussions on peacekeeping were unlikely to influence "other issues related to the political structure of the United Nations", including amendments to the Charter. This would be particularly true given signs that 
the C-33 might give up on elaborating "broad guidelines" for peacekeeping and instead begin considering "concrete aspects relative to the implementation of these operations", as desired by some troop-contributing countries.

Taking into account all of these factors, as well as Brazil's "reduced practical interest" in peacekeeping as a whole, the cable announced the decision to leave the Committee. Shortly after receiving the cabled instructions, Brazil's delegation in New York formalized the country's withdrawal from the C-33, the final step in Brazil's disengagement from UN peacekeeping (United Nations, 1977).

\section{Other factors: the military regime and peacekeeping:}

The main reason for the 1967-1989 gap in Brazil's participation in UN peacekeeping is therefore that these operations simply did not fall within the priorities and worldview that drove the country's multilateral activism in that period. That is not, however, the only reason. Foreign policy decisions rarely derive from a single cause, and in this case, the particular characteristics of the military regime in Brazil probably also contributed to country's decision to distance itself from UN peacekeeping.

As mentioned above, nothing prevents a military or authoritarian regime from contributing to peacekeeping operations and many indeed have done and do so. In Brazil's case, however, the military character of the regime may well have dampened the enthusiasm for making such a contribution.

The dictatorship that was put into place by the coup d'état in 1964 was an "institutional" one, in the sense that power was concentrated not in the hands of a single individual - a Franco or a Salazar-type figure - but in those of the Armed Forces, especially the Army. To a greater or lesser degree, the five Generals who held the 
Brazilian Presidency in succession all had to contend with the interests, influence, and vanities of their colleagues in uniform. The views of the military brass therefore carried weight in all areas of government - including foreign policy.

In 1967 and 1968, the military regime also accentuated its authoritarian character, with the coming to power of General Costa e Silva and the imposition of "Institutional Act n. 5" (AI-5), the brutal decree that suspended whatever was left of civil liberties and helped spread an epidemic of torture in Brazilian military and police installations. More than ever before, Brazil's military focused its attention and resources on combating socalled "terrorists" and "subversive elements", such as the members of the guerrilla movement in the area of the Araguaia River. In this context of "war at home", it is very much open to question whether Army chiefs would have looked favorably on proposals by the Ministry of External Relations to send troops abroad to participate in peacekeeping exercises (Napolitano, 2014; Martins, 1986).

The progressively worsening human rights situation in Brazil and the accompanying outcry abroad would also have dampened any enthusiasm for putting Brazilian troops in the limelight of international peacekeeping. Brazil's attitude towards human rights issues in general and the country's own record in particular was profoundly defensive. ${ }^{13}$ Sending Brazilian troops to help "maintain peace" abroad might have drawn unwelcome attention to the very different role they were playing within their own country's borders.

\footnotetext{
${ }^{13}$ In his memoirs, former Minister of External Relations Ramiro Saraiva Guerreiro might have alluded in a sibylline manner to this concern, when commenting why Brazil did not run for a seat on the Security Council, stating that there, "even more than in the Assembly, because in a small group every vote counts for a lot we would be subject to pressures and/or efforts by other countries to use us for their own ends, without any benefit to us" (Saraiva Guerreiro, 1992: 45). For one account of international scrutiny of human rights violations in Brazil and the discomfort it caused in Brazilian authorities, see Green (2010).
} 
Additionally, military perceptions were influenced by the chaotic circumstances involving UNEF I withdrawal. Caught in the crossfire of the Six Day War between Arab and Israeli forces, with Brazilian casualties, a generation of military officers learned to distrust the UN and its efforts to maintain peace. The political and logistic confusion that accompanied the operation's withdrawal probably left many Brazilian officers leery of donning blue helmets again in the future (Arraes, 2009: 219-242).

\section{The resumption of Brazil's participation in peacekeeping:}

Brazil's return to democracy hit its stride between 1985 and 1990, when a civilian was elected president (1985), a new constitution was adopted (1988), a direct presidential election was held (1989) and a new president was inaugurated (1990) - the first time since 1961 that a civilian transmitted the office to another civilian. President José Sarney (1985-1990) predicated his foreign policy on using the return to democratic rule to reconstruct Brazil's international reputation, seeking to erase the image of a "rejectionist" or "defensive" power, particularly regarding so-called new issues such as environment and human rights. The country signed and ratified major treaties in both areas and expanded its substantive engagement in international fora. In 1987, the Minister of External Relations announced that Brazil would run for a seat on the Security Council in the 1988-1989 term. Its successful election ended an almost twenty year absence from the Council (Fonseca, 2001; Seixas Corrêa, 2012; Côrtes, 2010).

This approach was largely maintained by Sarney's three immediate successors (Fernando Collor de Mello, 1990-1992; Itamar Franco, 1992-1994; Fernando Henrique Cardoso, 1995-2002). It both reflected and accelerated an erosion of the worldview that had guided Brazilian diplomacy in the previous decades. The debt crisis of the 1980s 
displayed the limits of trying to overcome international economic constraints through multilateral political action (Bueno, 1994: 94). The end of the Cold War seemed to herald a new fluidity in international politics, where the idea of "freezing of world power" lost much of its interpretive power. In short, the ascendancy of liberal democratic forces both within Brazil and in the international system more broadly led Brazilian diplomacy to make a significant strategic adjustment. Before, selective, defensive multilateral engagement was seen as a way to resist the consolidation of an international order inimical to the interests of developing countries. Now, in a context of less rigidity, multilateral engagement was a chance to strengthen the country's credentials and to help shape the many new international regimes that were coming into being or renewing themselves (Ferreira, 2006: 119-136).

One of the international transformations triggered by the thawing of the Cold War was the rapid expansion of peacekeeping operations. Under the watchful but enthusiastic eyes of the permanent members of the Security Council, a number of new operations were created, their ranks filled by troops both from traditional contributors and from the Warsaw Pact countries. This blooming of peacekeeping was seen as evidence of the United Nations' recovery of a central place in the international arena (Kertcher, 2012; Fontoura, 2005).

In contrast with the 1970s, when the peacekeeping scenario seemed bleak and dominated by a few manipulative great powers, acting under the UN flag now presented itself as an opportunity for Brazil to take part in meritorious international action to reestablish itself as a relevant player. The initial resumption of contributions was timid and framed as an attempt to contribute to solving conflicts in areas of direct interest, such as Angola and Central America - a framework preferred by many developing countries by that time. Brazil resumed its contribution in 1989, deploying 8 
military observers to the first United Nations Angola Verification Mission (UNAVEM I), to which it also contributed the Commander of the Military Observer Corps. Brazil's reintegration into peacekeeping activities was slow, as both diplomats and military officers had to relearn the long-forgotten lessons of UNEF I and reacquire confidence in international organizations, while at the same time following the rapid evolution in the practices and challenges of UN peacekeeping (Brazil, 1989; Kertcher, 2012; Uziel, 2010).

In the following years, Brazil would deploy military observers and staff officers in another mission in Angola (UNAVEM II); to ONUCA, in Central America; and to ONUSAL, in El Salvador. In 1993, Brazil deployed its first formed contingent to a peacekeeping mission since Suez, to the United Nations Operation in Mozambique (ONUMOZ). By that time, peacekeeping operations would be fully incorporated into the practice and preferences of great powers and were treated almost as a panacea for the numerous conflicts erupting around the globe. Accordingly, by 1992, Brazil had reincorporated into its diplomatic rhetoric the notion of being a frequent and traditional contributor to peacekeeping missions, highlighting this as evidence of its commitment to United Nations collective security (Fontoura, 2009; Seixas Corrêa, 2012: 665-677).

\section{Conclusion}

There is nothing particularly remarkable about a country not contributing troops to UN peacekeeping at any given period. Especially during the Cold War, when there were fewer and smaller operations, many States did not participate in peacekeeping for a number of reasons - including the fact that they were never asked to do so. Brazil's 1967-1989 absence from peacekeeping is noteworthy for three reasons: because it had contributed before; because this absence coincided with a period of heightened 
multilateral activism on the part of Brazilian diplomacy; and because of how quickly the country made "troop contributing country" an important part of its international identity after the end of the Cold War.

Not participating in peacekeeping is by and large a "non-policy", particularly in a period of fewer such operations. Brazil did not have to actively negotiate to keep its troops out of such missions: essentially, it just had to sit back and not volunteer. There is therefore much less concrete evidence and explanation for this policy than there is, for instance, for Brazil's active opposition to the Non-Proliferation Treaty, which was the subject of numerous speeches, cables, and memoranda.

Nevertheless, there is sufficient evidence to suggest that Brazil's absence from peacekeeping did not simply result from the 1964 coup d'état, the deepening of repression in 1968, or from an oversight or a casual lack of interest. On the contrary, this absence arose from a pressing and conscious concern regarding Brazil's place in world affairs and the role of the permanent members of the Security Council - especially the two superpowers - in the control of these operations. From 1967 to 1977, Brazil actively participated in the diplomatic struggle to determine the "institutional ownership" of peacekeeping operations - that is, the respective roles and responsibilities of the Security Council, the General Assembly, the Secretary General, and member states, in particular those contributing troops. From Brazil's point of view, a fairer distribution of these responsibilities would mean that peacekeepers would be less prone to manipulation by the great powers - a sign of better balance between great and middle and small powers in the UN. Under such circumstances, contribution of troops could have become more attractive.

It was not to be, however. By 1977, having lost hope of curbing the growing influence of the permanent members of the Security Council over peacekeeping 
operations, Brazil left the Special Committee (C-33) and ceased its active engagement with the issue for almost a decade. Blue-helmeted Brazilians would only be seen again in 1988, by which time the country, the international system, and the face of peacekeeping had all undergone immense transformations.

\section{References}

\section{Brazilian Official Documents:}

BRASEMB LiMA. Telegrama 498, 12/4/1967.

BRASIL. Diário do Congresso Nacional (Seção I), vol. XI, n. 203, 11/14/1956a.

BRASIL. Diário do Congresso Nacional (Seção I), vol. XI, n. 204, 11/15/1956b.

BRASIL. Diário do Congresso Nacional (Seção I), vol. XI, n. 207, 11/20/1956c.

BRASIL. Diário do Congresso Nacional (Seção I), vol. XI, n. 208, 11/21/1956d.

BRASIL. Discurso do Presidente José Sarney em visita a Angola - Encontro com Deputados da Assembléia do Povo, 27/1/1989. http://www.biblioteca.presidencia.gov.br/expresidentes/jose-sarney/discursos/1989/07.pdf Accessed on 1/9/2015

DELBRASONU. Telegrama 1105, 7/21/1973a.

DeLBRASONU. Ofício 789, 10/23/1973b.

DelBRASONU. Telegrama 1929, 11/2/1973c.

DELBRASONU. Telegrama 1944, 11/3/1973d.

DelBRASONU. Telegrama 2011, 11/8/1973e.

DELBRASONU. Telegrama 2347, 11/27/1973f. 
MinistÉRIO DAS RELAÇões EXTERIORES (MRE). Brazil - Candidate for the United Nations Security Council 2010-2011. Brasília: MRE, 2009.

Secretaria de Estado das Relações Exteriores (SERE). Despacho telegráfico para Delbrasonu 1080, 11/5/1973a.

SECRETARIA DE ESTAdo DAS RelaçÕES EXTERIORES (SERE). Despacho telegráfico para Delbrasonu 1247, 11/20/1973b.

SECRETARIA DE ESTAdo DAs RELAÇÕES EXTERIORES (SERE). Despacho telegráfico para Delbrasonu 456, 5/17/1977.

Other Sources:

Altemani de Oliveira, Henrique. Política externa brasileira. São Paulo: Saraiva, 2005.

Amado, Rodrigo (Org.). Araújo Castro. Brasília: Universidade de Brasília, 1982.

Amorim, Celso. "O Brasil e o Conselho de Segurança das Nações Unidas". Política Externa, vol. 3, n. 4, 1995.

Andesson, andreas. "Democracies and UN Peacekeeping Operations, 1990-1996. In. International Peacekeeping, vol. 7, nº. 2, 2000.

- "United Nations Intervention by United Democracies?: State Commitment to UN Interventions 1991-99". Cooperation and Conflict, vol. 37, nº. 4, 2002.

Araújo Castro, João Augusto de. "The United Nations and the Freezing of the International Power Structure". In. International Organization, vol. 26, n. 1, 1972.

Arraes Filho, Manoel Ricardo. A Construção da História e da Memória do Batalhão Suez, 2008. http://www.batalhaosuez.com.br/batsuezConstrucaoDaHistoria.htm Accessed on 1/9/2015.

. História, Memória e deserto - os soldados brasileiros no Batalhão Suez (1957-1967).

PhD Thesis, Universidade Federal Fluminense, 2009. 
Brito Cruz, José Humberto. "Aspectos da evolução da diplomacia brasileira no período da 'Política Externa Independente'“. In: Danese, Sérgio F. (Org.). Ensaios de História Diplomática do Brasil (1930-1986). Brasília: IPRI, 1989.

Bueno, C. "A política multilateral brasileira". In. Cervo, A. et alii. O Desafio Internacional. Brasília: Universidade de Brasília, 1994.

and Cervo, Amado. História da Política Exterior do Brasil. Brasília: Universidade de Brasília, 2001.

Campbell, Thomas. Masquerade Peace. America's UN Policy 1944-1945. Tallahassee: Florida State University Press, 1973.

Campos, Roberto. A Lanterna na Popa-Memórias. Rio de Janeiro: Topbooks, 2004.

Cançado Trindade, Antônio Augusto. "Posições Internacionais do Brasil no Plano Multilateral" In. Revista Brasileira de Estudos Políticos, n. 52, 1981.

Cardoso, Afonso J. S. O Brasil nas Operações de Paz das Nações Unidas. Brasília: FUNAG, 1998.

Claude Jr., Inis. "The political framework of the United Nations' financial problems". In. International Organization, vol. 17, n. 4, 1963.

Côrtes, Octávio H. D. G. A Política Externa do Governo Sarney. Brasília: FUNAG, 2010.

Ferreira, Túlio Sérgio Henriques. "A ruína do consenso: a política exterior do Brasil no governo Figueiredo (de 1979 a 1985)". In. Revista Brasileira de Política Internacional, vol.49, n. 2, 2006.

Fonseca Jr, Gelson. "Notes on the Evolution of Brazilian Multilateral Diplomacy". In. Global Governance, vol. 17, 2001.

Fontoura, Paulo R. C. Tarrisse. O Brasil e as Operações de Manutenção da Paz das Nações Unidas. Brasília: FUNAG, 2005. 
. Brasil: 60 Anos de Operações de Paz. Rio de Janeiro: DPHDM, 2009.

Green, James N. We Cannot Remain Silent: Opposition to the Brazilian Military Dictatorship in the United States. Durham: Duke University Press, 2010.

Hurrell, Andrew. The Quest for Autonomy: The Evolution of Brazil's Role in the International System, 1964-1985. Brasília: FUNAG, 2013.

Kertcher, Chen. "From Cold War to a System of Peacekeeping Operations: The Discussions on Peacekeeping in the UN during the 1980s up to 1992". In. Journal of Contemporary History, vol. 47, n. 3, 2012.

Lannes, Suellen Borges. O Batalhão Suez e a política externa de JK: Um caso de alinhamento?. Master's dissertation, Universidade Federal Fluminense, 2009.

Ligiéro, Luiz Fernando. A Autonomia na Política Externa Brasileira - a política externa independente e o pragmatismo responsável: momentos diferentes, políticas semelhantes? Brasília: FUNAG, 2011.

Lima, Maria Regina Soares. "Enfoques Analíticos de Política Exterior: El Caso Brasileño". In. Russell, Roberto (ed.). Enfoques Teóricos y Metodológicos Para El Estudio de la Política. Buenos Aires: Grupo Editor Latinoamericano S. R. L., 1992.

Martins, Roberto. Segurança Nacional. São Paulo: Brasiliense, 1986.

Mello e Silva, Alexandra. "Desenvolvimento e Multilateralismo: Um estudo sobre a Operação Pan-Americana no contexto da política externa de JK". In. Contexto Internacional, vol. 14, n. 2, 1992.

Moura, Gerson. Autonomia na dependência : a política externa brasileira de 1935 a 1942. Rio de Janeiro: Nova Fronteira, 1980.

Napolitano, Marcos. 1964 - História do Regime Militar Brasileiro. São Paulo: Contexto, 2014.

Pinheiro, Leticia. “Traídos pelo Desejo: Um Ensaio sobre a Teoria e a Prática da Política Externa Brasileira Contemporânea". In. Contexto Internacional, vol. 22, n. 2, 2000. 
Review of the History and Evolution of the Special Committee on Peacekeeping. Photocopy, produced by the Secretariat of the United Nations. New York: 1999 (?).

Santos, Norma. B. “O Brasil e a Questão Israelense nas Nações Unidas”. In. Brasil e Israel - Diplomacia e Sociedade. Brasília: Universidade de Brasília, 2000.

.. "Dez Anos no deserto: a participação brasileira na primeira missão de paz das Nações Unidas". In. DuPAS, Gilberto and VIGEVANI, Tullo. Israel-Palestina: a construção da paz vista de uma perspectiva global. São Paulo: UNESP, 2002.

Saraiva Guereiro, Ramiro. Lembranças de um Empregado do Itamaraty. São Paulo: Siciliano, 1992.

Seixas Corrêa, Luiz Felipe de. O Brasil nas Nações Unidas, 1946-2011. Brasília: FUNAG, 2012.

Spektor, Matias, Uncovering the Sources of Nuclear Behavior: Brazil (forthcoming).

United NATIONS. "Certain expenses of the United Nations (Article 17, paragraph 2 of the Charter), Advisory Opinion of 20 July 1962", I. C. J. Reports 1962.

United Nations. Letter dated 19 December 1977 from the Permanent Representative of Brazil to the United Nations addressed to the Secretary-General (A/32/493). New York: United Nations, 1977.

United NATIONS. Middle East - UNEF I Facts and Figures. New York: United Nations, 2014. http://www.un.org/en/peacekeeping/missions/past/unef1facts.html Accessed on $1 / 9 / 2015$.

Urquhart, Brian. A Life in Peace and War. New York: Harper \& Row, 1987.

Uziel, Eduardo. O Conselho de Segurança, as Operações de Manutenção da Paz e a Inserção do Brasil no Mecanismo de Segurança Coletiva das Nações Unidas. Brasília: FUNAG, 2010.

- "O Voto do Brasil e a condição de membro eletivo no Conselho de Segurança das Nações Unidas". In. Política Externa, vol. 21, n. 1, 2012. 
and Vargas, João A. C. “O Comitê Especial de Operações de Manutenção da Paz (C-34)". In. Revista Marítima Brasileira, vol. 131, n. 4/6, 2011.

Vargas, João A. C. Um mundo que também é nosso: o pensamento e a trajetória diplomática de Araujo Castro. Brasília: FUNAG, 2013.

Viotti, Maria Luíza Ribeiro. Brazil in the Security Council, 2011. https://web.archive.org/web/20140903213031/http://www.un.int/brazil/book/conselhoSe curanca_index.html, accessed on 1/9/2015.

Vizentini, Paulo Fagundes. A política externa do regime militar brasileiro. Porto Alegre: UFRGS, 2004.

Weis, W. Michael. Cold Warriors \& Coups d'état: Brazilian-American relations, 1945-1964. Albuquerque: University of New Mexico, 1993. 